\title{
Pengujian Pupuk Organik Cair dari Eceng Gondok (Eichhornia crassipes) Terhadap Pertumbuhan Tanaman Sawi (Brassica juncea)
}

\section{Anastasia R. Moia*, Dingse Pandiangana, Parluhutan Siahaana, Agustina M Tangapo a}

aJurusan Biologi, FMIPA, Unsrat, Manado

\section{K A T A K U C I}

pupuk organik cair

Eichhornia crassipes

Brassica juncea

\section{K E Y W O R D S}

Liquid organic fertilizer

Eichhornia crassipes

Brassica juncea
AVAILABLE ONLINE 10 Februari 2015

\begin{abstract}
A B S TR A K
Penelitian ini bertujuan untuk mengetahui pengaruh pemberian pupuk organik cair terhadap tinggi, berat basah, berat kering, dan jumlah daun tanaman sawi. Pupuk cair organik yang digunakan dalam penelitian ini berasal dari proses fermentasi Eichhornia crassipes. Perlakuan yang diberikan yaitu, kontrol air atau tanpa perlakuan pupuk organik cair, perlakuan dengan NPK, dengan pupuk organik cair $10 \%$, pupuk organik cair 20\%, 30\% dan 40\%. Parameter yang diamati tinggi tanaman, jumlah daun, berat basah dan berat kering tanaman sawi. Tinggi tanaman tertinggi terdapat pada perlakuan dengan pupuk organik cair $40 \%$, dan kontrol air pada parameter tinggi taman menunjukkan hasil yang beda nyata kepada semua perlakuan. JumLah daun paling banyak terdapat pada perlakuan dengan NPK dan pupuk organik cair $40 \%$. Berat basah dan berat kering yang paling berat terdapat pada pupuk organik cair $40 \%$ dengan berat masing-masing 154,93 g dan 44,1 g. Berdasarkan hasil yang diperoleh dapat disimpulkan bahwa pemberian pupuk organik cair dapat meningkatkan tinggi tanaman, jumlah daun, berat basah dan berat kering tanaman sawi.

\section{A B S T R A C T}

This study aimed to determine the effect of liquid organic fertilizer to height, fresh weight, dry weight, and number of leaves of mustard. Organic liquid fertilizer used in this study is derived from the fermentation process Eichhornia crassipes. The treatments were given, namely, control of the untreated water or liquid organic fertilizer, NPK treatment, with $10 \%$ liquid organic fertilizer, liquid organic fertilizer 20\%, 30\% and $40 \%$. The parameters observed plant height, number of leaves, fresh weight and dry weight of mustard. The highest plant height are on treatment with 40\% liquid organic fertilizer, and water control at high parameters park showed a significant difference to all treatments. Number of leaves are most numerous in the treatment with NPK and liquid organic fertilizer $40 \%$. Wet weight and dry weight are most severe in $40 \%$ organic liquid fertilizer each weighing $154.93 \mathrm{~g}$ and $44.1 \mathrm{~g}$. Based on the results obtained it can be concluded that the liquid organic fertilizer can increase plant height, number of leaves, fresh weight and dry weight of mustard.

\section{Pendahuluan \\ Pupuk organik adalah pupuk yang terbuat dari bahan-bahan organik seperti sisa-sisa sayuran,}

kotoran ternak dan sebagainya dan juga berasal dari mahluk hidup yang telah mati. Pembusukan dari bahan-bahan organik dan mahkluk hidup yang telah mati menyebabkan perubahan sifat fisik dari bentuk

*Corresponding author: Jurusan Biologi FMIPA UNSRAT, Jl. Kampus Unsrat, Manado, Indonesia 95115; Email address: moianastasia@ymail.com Published by FMIPA UNSRAT (2015) 
sebelumnya. Berdasarkan bentuknya, pupuk organik dibedakan menjadi dua, yaitu: pupuk cair dan pupuk padat (Hadisuwito, 2012). Pupuk organik cair adalah pupuk yang kandungan bahan kimianya dapat memberikan hara yang sesuai dengan kebutuhan tanaman pada tanah (Taufika, 2011).

Menurut Hadisuwito (2012) dan Soenandar et al. (2010) bahwa pupuk organik cair berasal dari penguraian bahan organik seperti daun tanaman dan kotoran hewan. Pupuk organik cair memiliki kelebihan antara lain mengandung dan mampu menyediakan unsur hara lengkap yang dibutuhkan oleh tanaman untuk tumbuh, memperbaiki struktur tanah, memperbaiki kehidupan mikroorganisme dalam tanah, pembagianya dapat lebih merata dan mudah digunakan

Keunggulan dari pupuk organik cair adalah dapat menyehatkan lingkungan, revitalisasi produktivitas tanah, menekan biaya, dan meningkatkan kualitas produk (Hadisuwito, 2012). Disamping itu keunggulan lain dari pupuk organik cair adalah mampu memperbaiki struktur tanah, menaikkan daya serap tanah terhadap air, menaikan kondisi kehidupan di dalam tanah.

Rozaq dan Novianto (2000 dalam Kristanto, 2003) menyatakan bahwa tumbuhan eceng gondok (E. crassipes) merupakan tumbuhan menahun yang tumbuh mengapung bila air tumbuhnya cukup dalam dan berakar di dasar. Eceng gondok adalah tumbuhan yang laju pertumbuhannya sangat cepat, tumbuhan air ini dianggap sebagai gulma air karena menyebabkan banyak kerugian yaitu berkurangnya produktivitas badan air seperti mengambil ruang, dan unsur hara yang juga diperlukan ikan. Eceng gondok merupakan bahan organik yang potensial, karena berdasarkan penelitian-penelitian terdahulu bahwa produksi eceng gondok di Bangladesh dapat mencapai lebih dari 300 ton per hektar per tahun (Sitadewi, 2007).

Kandungan kimia dari eceng gondok mengandung bahan organik sebesar $78,47 \%$, C organik $21,23 \%, \mathrm{~N}$ total $0,28 \%$, $\mathrm{P}$ total $0,0011 \%$, dan $\mathrm{K}$ total $0,016 \%$ sehingga dari hasil ini eceng gondok berpotensi untuk di manfaatkan sebagai pupuk organik karena eceng gondok memiliki unsur-unsur yang diperlukan tanaman untuk tumbuh (Rozaq dan Novianto, 2000 dalam Kristanto, 2003).

Sawi adalah tanaman berdaun besar dan hidup di tanah kering. Tanaman sawi merupakan tanaman sayuran daun yang mengandung zat-zat gizi lengkap yang memenuhi syarat kebutuhan gizi masyarakat sehingga apabila dikonsumsi sangat baik untuk kesehatan tubuh. Batang dari tanaman sawi ini sangat pendek sehingga hampir tidak terlihat. Batang pada sawi ini berfungsi untuk membentuk dan menopang daun (Nursanti, 2010).

Berdasarkan semua pernyataan di atas menunjukkan bahwa pupuk organik cair merupakan alternatif lain yang dapat digunakan untuk menggantikan pupuk anorganik. Sementara itu eceng gondok merupakan tanaman yang berpotensi untuk dimanfaatkan sebagai bahan dasar pembuatan pupuk organik cair oleh karena itu perlu dilakukan pengkajian secara ilmiah pengaruh pupuk organik cair yang berasal dari eceng gondok terhadap pertumbuhan tanaman sawi.

\section{Metode}

\subsection{Bahan dan Alat}

Alat yang digunakan yaitu komposter, polybag, sprayer, panci, kompor, parutan, gelas ukur, gelas aqua, mistar, timbangan, dan oven.

Bahan yang digunakan yaitu eceng gondok, bibit sawi, susu sapi murni, terasi, gula pasir, bekatul, nenas, air bersih, usus ayam, tanah kompos dan pupuk NPK.

\subsection{Penyiapan Eceng Gondok}

Eceng gondok yang akan digunakan diambil dan dikumpulkan dari Danau Tondano dan dibawa ke Laboratorium Konservasi FMIPA UNSRAT untuk dibersihkan dan dibuat pupuk organik cair. Pembuatan pupuk organik cair, pembibitan tanaman sawi dan perlakuan percobaan dilakukan di Perumahan Bumi Kawangkoan Baru Blok B No 8, dan perhitungan parameter berat basah dan berat kering di Laboratorium Konservasi FMIPA UNSRAT

\subsection{Pembuatan EM (Effectif Mikroorganisme)}

Efektif Mikroorganisme (EM) dibuat mengikuti prosedur pembuatan dari Hadisuwito, (2012). Cara pembuatan EM yaitu, buah nenas 500 g dihaluskan dengan parutan, setelah itu terasi $1 / 2 \mathrm{~kg}$, bekatul $1 \mathrm{~kg}$, dan gula pasir $1 \mathrm{~kg}$, dicampurkan dengan air bersih 10 L di dalam panci, kemudian dimasak hingga mendidih, lalu didinginkan. Susu 2 L, dan usus ayam 500 g ditambahkan, kemudian diaduk hingga tercampur merata. Campuran yang telah dibuat selanjutnya ditutup rapat-rapat selama 12 jam atau satu hari. Bila sudah siap jadi akan menjadi kental atau lengket. EM dikatakan berhasil apabila munculnya gelembung-gelembung di permukaan bahan.

\subsection{Pembuatan Pupuk Organik Cair}

Pupuk organik cair dibuat mengikuti prosedur pembuatan dari Hadisuwito (2012) yaitu pertama, eceng gondok yang telah diambil dari danau Tondano dipisahkan dari sampah non organik. Eceng gondok selanjutnya dirajang atau dipotong-potong agar proses fermentasinya berlangsung sempurna, selanjutnya larutan EM disiapkan dengan spayer bervolume $1 \mathrm{~L}$ disiapkan, kemudian spayer ini diisi dengan air, sebaiknya digunakan air sumur karena tidak mengandung kaporit. EM dituangkan kedalam spayer dengan perbandingan $1 \mathrm{~L}$ air dicampurkan sebanyak 1-2 tutup botol aqua EM, kemudian larutan dikocok sampai merata. Eceng gondok yang telah dirajang kemudian disemprot dengan larutan EM hingga merata ke seluruh bagian, kemudian dituangkan ke dalam komposter dan ditutup rapat. Awal pemakaian akan menghasilkan lindi atau pupuk cair setelah 2 minggu. 


\subsection{Pembibitan Sawi}

Pembibitan sawi dilakukan dengan urutan yaitu, persiapan lahan, dan tempat untuk persemaian, pemilihan bibit, persemaian dan perawatan bibit sawi.

Pembuatan persemaian atau pembibitan tanaman sawi yaitu di tanah bedengan khusus untuk pembibitan. Benih yang akan di semaikan direndam di dalam air selama kurang lebih 2 jam sebelum ditabur. Benih yang mengambang dibuang sedangkan yang tenggelam akan disemaikan. Setelah selesai direndam, benih sawi ditaburkan secara merata di media semai, lalu disiram sampai basah, selanjutnya ditutup dengan daun pisang selama 3 hari. Pada hari ketiga, daun pisang disingkirkan, dan benih dibiarkan tumbuh berkembang dengan baik. Setelah benih berumur 2-3 minggu, bibit siap untuk dipindahkan ke polybag.

Bibit yang telah siap diambil, kemudian dimasukan 2 bibit kedalam polybag yang telah diisi dengan tanah kompos. Setelah penanam selesai, kemudian dilakukan penyiraman hingga cukup basah untuk mencegah agar bibit yang sudah ditanam tidak mati. Penanaman dilakukan pada sore hari agar tidak layu karena panas matahari.

\subsection{Perlakuan Pemberian Pupuk}

Untuk perlakuan akan diberikan 5 perlakuan dan masing-masing perlakuan dengan 3 ulangan, dengan rincian sebagai berikut:

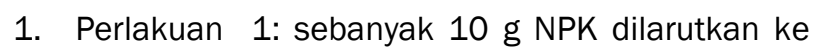
dalam $5 \mathrm{~L}$ air, diberi perlakuan dengan menyiram ke setiap polybag $100 \mathrm{~mL}$

2. Perlakuan 2: Perlakuan Pupuk organik cair $10 \%$ (10 mL Pupuk organik cair dan $90 \mathrm{~mL}$ air)

3. Perlakuan 3: Perlakuan Pupuk organik cair $20 \%$ (20 mL Pupuk organik cair dan $80 \mathrm{~mL}$ air)

4. Perlakuan 4: Perlakuan Pupuk organik cair $30 \%$ (30 mL Pupuk organik cair dan $70 \mathrm{~mL}$ air)

5. Perlakuan 5: Perlakuan Pupuk organik cair $40 \%$ (40 mL Pupuk organik cair dan $60 \mathrm{~mL}$ air)

Pemupukan dilakukan setiap 4 hari sekali sedangkan penyiraman dengan air dilakukan setiap hari kecuali saat pemberian pupuk.

\subsection{Analisis Data}

Pengolahan data yang akan dilakukan yaitu dengan analilis varian (ANAVA) pada tingkat kepercayaan $5 \%$, apabila terdapat variasi diantara perlakuanmaka kemudian dilanjutkan dengan UBT (Uji Beda Terkecil) 5\%.

\section{Hasil dan Pembahasan}

Salah satu parameter yang diamati adalah tinggi tanaman yang dapat dilinat pada Tabel 1. Menunjukan bahwa pada tinggi tanaman sawi yang mengalami pertumbuhan yang tinggi yaitu pada perlakuan pupuk organik cair $40 \%$ hal ini disebabkan semakin banyak pupuk organik yang diberikan maka semakin tinggi pertumbuhan tanaman. Hal ini sesuai dengan yang dikemukakan oleh Rizqiani et al (2007) bahwa semakin tinggi dosis pupuk yang diberikan maka kandungan unsur hara yang diterima oleh tanaman akan semakin tinggi.

Kandungan dalam unsur $\mathrm{N}$ pada pupuk organik membentuk protein dan klorofil, oleh karena itu apabila kekurangan klorofil akan menyebabkan berkurangnya kemampuan tanaman untuk memproduksi karbohidrat, sementara itu kekurangan protein dapat mempengaruhi pertumbuhan sel vegetatif (Hadisuwito, 2012).

Pupuk organik cair $40 \%$ berbeda nyata dengan pupuk organik cair $10 \%$, dan pupuk organik cair $30 \%$ dan NPK tidak berbeda nyata berdasarkan uji BNT $5 \%$. Artinya pemberian dengan pupuk organik cair $40 \%$ berbeda pengaruhnya dengan pupuk organik cair $10 \%$, begitu pula dengan pupuk organik cair $30 \%$ memberikan pengaruh yang berbeda dengan NPK.

Tabel 1 - Tinggi terakhir tanaman sawi $(\mathrm{cm})$ yang mengalami perlakuan kontrol, NPK, POC $10 \%$, POC $20 \%$, POC $30 \%$, dan POC $40 \%$ pada uji BNT $5 \%$.

\begin{tabular}{|l|l|}
\hline Perlakuan & Tinggi Tanaman $(\mathrm{cm}) \pm S D$ \\
\hline Kontrol & $25,1 \pm 1,01 \mathrm{a}$ \\
\hline NPK & $40 \pm 2,64 \mathrm{~d}$ \\
\hline POC. $10 \%$ & $33,3 \pm 1,25 \mathrm{~b}$ \\
\hline POC. $20 \%$ & $36,06 \pm 1,27 \mathrm{c}$ \\
\hline POC.30\% & $39,86 \pm 1,43 \mathrm{~d}$ \\
\hline POC.40\% & $44,1 \pm 3,77 \mathrm{e}$ \\
\hline
\end{tabular}

*SD: Standart Deviasi

Semakin banyak unsur $\mathrm{N}$ yang diterima tanaman sawi melalui pupuk organik cair maka semakin tinggi pula tinggi dari tanaman sawi. Hal ini dikarnakan bahan organik yang ada pada eceng gondok telah diuraikan oleh mikroorganisme sehingga unsur-unsur organik pada pupuk organik cair ini membantu menyediakan N bagi tanaman (Hadisuwito, 2012).

Parameter lain yang diamati adalah jumlah daun. Tabel 2 yaitu jumlah daun dapat dilihat bahwa kontrol yang dalam hal ini adalah air memiliki rata-rata jumlah daun yang paling sedikit bila dibandingkan dengan perlakuan NPK, pupuk organik cair $10 \%, 20 \%$, $30 \%$ dan 40\%, tetapi berdasarkan uji BNT 5\% dapat dilihat bahwa antara kontrol dengan dengan pupuk organik cair $10 \%$ dan $20 \%$ berbeda nyata, kedua perlakuan ini memberikan pengaruh yang berbeda. Perlakuan dengan pupuk organik $40 \%$ dan NPK menunjukkan bahwa dari kedua perlakuan ini berdasarkan uji BNT 5\% tidak berbeda nyata. Artinya antara pupuk organik cair $40 \%$ dan NPK tidak memberikan pengaruh yang berbeda. Perlakuan dengan kontrol air, pupuk organik cair $20 \%$ berbeda nyata dengan perlakuan dengan NPK, pupuk organik cair $30 \%$ dan pupuk organik cair $40 \%$ berdasarkan uji BNT 5\%.

Ketersediaannya unsur hara yang sesuai dan memenuhi kebutuhan dari tanaman akan sangat 
membantu pertumbuhan dari tanaman itu sendiri. Pupuk organik memiliki kandungan unsur hara makro dan mikro yang dibutuhkan tanaman, tetapi kandungan atau kadar dari unsur-unsur tersebut tergolong rendah, oleh karena itu aplikasinya ke tanaman harus dalam jumlah yang banyak (Rauf et al., 2000). Pada penelitian ini jelas terlihat bahwa semakin tinggi perlakuan pupuk yang diberikan maka semakin banyak jumLah daun dari tanaman sawi tersebut.

Tabel 2 - Jumlah daun tanaman sawi yang mengalami perlakuan kontrol, NPK, POC 10\%, POC $20 \%$, POC $30 \%$, dan POC $40 \%$ pada uji BNT $5 \%$.

\begin{tabular}{|l|l|}
\hline Perlakuan & Jumlah Daun \pm SD \\
\hline Kontrol & $8,66 \pm 2,08 \mathrm{a}$ \\
\hline NPK & $13 \pm 2,64 \mathrm{e}$ \\
\hline POC.10\% & $9,66 \pm 1,52 \mathrm{~b}$ \\
\hline POC.20\% & $10,66 \pm 1,52 \mathrm{c}$ \\
\hline POC.30\% & $11,33 \pm 2,08 \mathrm{~d}$ \\
\hline POC.40\% & $13 \pm 2,64 \mathrm{e}$ \\
\hline
\end{tabular}

*SD: Standart Deviasi

Berat basah adalah salah satu parameter yang diamati pada penelitian ini, dapat dilihat bahwa semakin tinggi perlakuan pupuk yang diberikan maka semakin berat, berat basah dari tanaman sawi ini. Tabel 3 yaitu tentang berat basah yang menunjukkan bahwa dari perlakuan yang dilakukan maka pemberian pupuk dengan perlakuan yang paling rendah atau $10 \%$ adalah perlakuan yang memiliki berat basah yang paling rendah atau kecil. Berbanding terbalik dengan perlakuan pupuk organik cair paling besar atau perlakuan pupuk organik cair $40 \%$ adalah perlakuan dengan berat basahnya paling tinggi.

Erawan et al., (2013) menyatakan bahwa apabila unsur $\mathrm{N}$ yang disuplai oleh pupuk tersedia dengan baik maka tumbuhan tersebut akan mengalami pertumbuhan yang baik. Penelitian ini menunjukkan bahwa unsur $\mathrm{N}$ yang disuplai dari pupuk organik cair dan NPK dapat terpenuhi sehingga tanaman sawi dapat tumbuh dengan baik dan menghasilkan berat basah yang baik pula.

Hasil BNT 5\% menunjukkan bahwa antara perlakuan pupuk cair organik $10 \%$ berbeda nyata dengan pupuk organik cair 20\%, 30\%, 40\% dan NPK, maka perlakuan pupuk organik cair $10 \%$ memberikan pengaruh yang berbeda dengan pengaruh yang diberikan dari pupuk organik cair 20\%, 30\%, 40\%, dan NPK pada berat basah dari tanaman sawi. Nurshanti (2010) menyatakan bahwa semakin tinggi tanaman maka semakin berat juga bobot tanaman tersebut. Hal senada juga dikemukakan oleh Zuhry dan Armaini (2009) yang menyatakan bahwa penambahan unsur $\mathrm{N}$ yang sesuai kebutuhan akan membuat tanaman tumbuh dengan baik dan semakin besar tinggi tanaman dan jumLah daun maka berat basah tanaman sawi semakin meningkat. Hal ini sesuai dengan penelitian ini dimana pupuk organik cair dengan perlakuan $40 \%$ adalah perlakuan yang memiliki tinggi tanaman dan jumlah daun tertinggi oleh sebab itu pada parameter berat basah yang diamati ini perlakuan pupuk organik 40\% adalah perlakuan yang memiliki bobot berat basah tertinggi.

Tabel 3 - Berat basah tanaman sawi (g) yang mengalami perlakuan control, NPK, POC $10 \%$, POC $20 \%$, POC $30 \%$, dan POC $40 \%$ pada uji BNT $5 \%$.

\begin{tabular}{|l|l|}
\hline Perlakuan & Berat Basah(g) \pm SD \\
\hline Kontrol & $8,66 \pm 2,08 \mathrm{a}$ \\
\hline NPK & $13 \pm 2,64 \mathrm{e}$ \\
\hline POC.10\% & $9,66 \pm 1,51 \mathrm{~b}$ \\
\hline POC.20\% & $10,66 \pm 1,52 \mathrm{c}$ \\
\hline POC.30\% & $11,33 \pm 2,08 \mathrm{~d}$ \\
\hline POC.40\% & $13 \pm 2,64 \mathrm{e}$ \\
\hline
\end{tabular}

*SD: Standart Deviasi

Tabel 4 - Berat kering tanaman sawi (g) yang mengalami perlakuan kontrol, NPK, POC $10 \%$, POC $20 \%$, POC $30 \%$, dan POC $40 \%$ pada uji BNT $5 \%$

\begin{tabular}{|l|c|}
\hline Perlakuan & Berat kering (g) \pm SD \\
\hline Kontrol & $2,51 \pm 1,03 \mathrm{a}$ \\
\hline NPK & $40 \pm 1,15 \mathrm{~d}$ \\
\hline POC.10\% & $33,3 \pm 1,53 \mathrm{~b}$ \\
\hline POC. $20 \%$ & $36,06 \pm 1,32 \mathrm{c}$ \\
\hline POC.30\% & $39,86 \pm 1,30 \mathrm{~d}$ \\
\hline POC.40\% & $44,1 \pm 2,70 \mathrm{e}$ \\
\hline
\end{tabular}

*SD: Standart Deviasi

Pada parameter selanjutnya yaitu pada parameter berat kering. Parameter berat kering tanaman ini diperoleh dari setelah panen, tanaman sawi ini ditimbang berat basahnya, kemudian setelah diperoleh berat basah maka tanaman sawi ini selanjutnya dioven pada suhu $50^{\circ}$ C sampai mencapai berat konstan. Berat konstan inilah yang menjadi berat kering pada tanaman sawi dari penelitian ini. Berdasarkan uji BNT 5\% yang terdapat pada Tabel 4 terlihat bahwa antara perlakuan pupuk organik cair $10 \%$ dan $20 \%$ berbeda nyata. Pada perlakuan pupuk organik $30 \%$ dengan NPK berdasarkan uji BNT 5\% menunjukkan hasil yang tidak berbeda nyata. Uji BNT 5\% juga menunjukkan bahwa perlakuan pupuk organik 40\% adalah perlakuan pupuk yang menunjukkan beda nyata dengan perlakuan pupuk organik cair 10\%, 20\%, 30\% dan NPK. Semua perlakuan yang diberikan kepada tanaman sawi ini menunjukkan bahwa semua perlakuan ini baik dari perlakuan pupuk organik cair 10\%, 20\%, 30\%, 40\% dan NPK berbeda nyata dengan kontrol berdasarkan uji BNT 5\%, kontrol memberikan pengaruh yang berbeda dengan perlakuan yang lainnya, pada perlakuan pupuk organik $40 \%$ memberikan pengaruh yang berbeda dengan pupuk organik cair 10\%,20\%, 30\%, dan NPK, sedangkan pada pupuk organik cair $30 \%$ dan NPK tidak 
memberikan pengaruh yang berbeda antara kedua perlakuan ini.

Rata-rata berat kering dari tanaman sawi pada penelitian ini, menunjukkan bahwa perlakuan pupuk organik cair $10 \%$ dan $20 \%$ adalah perlakuan pupuk yang memiliki berat kering terkecil, kemudian di ikuti dengan perlakuan pupuk organik cair 30\% dan NPK. Pupuk organik cair dengan perlakuan 40\% adalah perlakuan yang memiliki berat kering terbesar.

\section{Kesimpulan}

Kesimpulan yang dapat diambil dari penelitian ini adalah pemberian pupuk organik cair dapat meningkatkan tinggi tanaman, jumlah daun, berat basah dan berat kering tanaman sawi karena mengandung unsur-unsur mikro seperti $\mathrm{N}, \mathrm{P}$ dan $\mathrm{K}$ yang berguna bagi pertumbuhan tanaman sawi. Pertumbuhan tanaman sawi yang paling tinggi terjadi pada perlakuan dengan pupuk organik cair $40 \%$.

\section{Daftar Pustaka}

Erawan, D. Wa, O, Y. Andi, B. 2013. Pertumbuhan dan Hasil tanaman Sawi (Brassica juncea L) Pada Berbagai Dosis Pupuk UREA. Jurnal Agroteknos. 3 (1) : 19-25

Hadisuwito, S. 2012. Membuat Pupuk Organik Cair. PT. Agro Media Pustaka: Jakarta Selatan

Kristanto, B, A. 2003. Pemanfaatan gondok ( $E$. crassipes) sebagai bahan Eceng Jurnal UNDIP
Nurshanti, F. D. 2010. Pertumbuhan Produksi Tanaman Sawi

(B.

dan varietas berbeda. Jurnal Agronobis. 2 (4)

Rauf, W. A., Syamsuddin, T. Sihombing, R, S. 2000. Peranan Pupuk NPK pada Tanaman Padi. Jurnal LPTP. 1 (1) 1-9

Rizqani, N. F. Erlina, A. Nasih, W, Y. 2007. Pengaruh Dosis dan Frekuensi Pemberian Pupuk Organik Cair Terhadap Pertumbuhan dan Hasil Buncis (Phaseolus vulgaris L) Dataran Rendah. Jurnal IImu Tanah dan lingkungan. 7 (1) : 43-53

Soenandar, M., Nur, A, M.,Raharjo, A. 2010. Petunjuk Praktis Membuat Pestisida Organik. PT. Agro Media Pustaka: Jakarta Selatan

Sitadewi, E. H. 2007. Pengolahan Bahan Organik Enceng Gondok MenjadiMedia Tumbuh untuk Mendukung Pertanian Organik. JurnalTeknologi Lingkungan. 8 (3) : 229 234

Taufika, R. 2011. Pengujian Beberapa Dosis Pupuk Organik Cair TerhadapPertumbuhan dan Hasil Tanaman Wortel (Doucus carota L). Jurnal Tanaman. $1(2): 1-10$

Zuhry, E dan Armaini. 2009. Aplikasi Berbagai Pupuk Pelengkap Cair dan Pupuk Kandang Ayam Terhadap Peningkatan Produksi Sawi (Brassica juncea L). Jurnal Agroteknologi Fakultas Pertanian Universitas Riau. 8 : 22-28 